\title{
THE IMPORTANCE OF CONSIDERING POLLUTION ALONG THE COAST FROM HEAVILY MODIFIED WATER BODIES UNDER THE WATER FRAMEWORK DIRECTIVE
}

\author{
REGINA TEMINO-BOES, INMACULADA ROMERO, \\ REMEDIOS MARTINEZ-GUIJARRO \& MARIA PACHÉS \\ Instituto de Ingeniería del Agua y del Medio Ambiente, Universitat Politècnica de València, Spain
}

\begin{abstract}
The European Water Framework Directive aims to achieve a good status of all inland and coastal waters in the European Union by evaluating the status and the anthropogenic pressures to natural water bodies. As such, several techniques have been developed to evaluate the anthropogenic pressure to coastal areas. The most widespread methods are indexes, although some authors have also used the application of models. Using indexes has many advantages, such as the simplicity or the fast application. The anthropogenic pressure is generally assessed through the application of an index which is calculated based on parameters such as population density, urbanization, industry, agriculture, fisheries and maritime transport. However, the dispersion of contaminants along the coast is a factor that is generally overlooked by such indexes. Natural coastal waters have been widely assessed in Member States. On the contrary, heavily modified coastal waters, which are generally located close to the biggest urban areas, have been left aside in the evaluation process. To demonstrate that minimizing pollution in heavily modified coastal waters is a must, we evaluated several nutrient concentrations in natural coastal waters of the Jucar River Basin District, located in the Western Mediterranean Sea (Spain). We calculated the correlation between nutrient concentrations and several anthropogenic pressures, including the presence of adjacent water bodies considered as heavily modified by human activity under the Water Framework Directive. Then, a forward stepwise linear regression was applied to identify the activities most affecting nutrient concentrations. It was found that the presence of a neighbouring water body classified as heavily modified was the main driver of nutrient concentration differences among natural water bodies. These results suggest that the evaluation of anthropogenic pressures to coastal waters should also consider the dispersion of pollutants from adjacent heavily modified coastal waters. Keywords: coastal waters, diffusion, heavily modified water bodies, nutrients, Water Framework Directive.
\end{abstract}

\section{INTRODUCTION}

\subsection{Water Framework Directive}

The "Directive 2000/60/EC of the European Parliament and of the Council establishing a framework for the Community action in the field of water policy", commonly known as the Water Framework Directive (WFD) was published on the 22nd of December 2000. Some amendments have been introduced since then. The purpose of the WFD is to establish a framework for the protection of inland surface waters (rivers and lakes), transitional waters, coastal waters and groundwater. The main activities to be carried out within this directive are: the characterization of the River Basin Districts, pressures and impact evaluation, monitoring, establishment of environmental objectives and design and implementation of the programme of measures. Coastal waters are defined in the WFD as 'surface water on the landward side of a line, every point of which is at a distance of one nautical mile on the seaward side from the nearest point of the baseline from which the breadth of territorial waters is measured, extending where appropriate up to the outer limit of transitional waters'. 
When a body of surface water is substantially changed in character as a result of physical alterations by human activity (e.g. presence of a harbour), this water body is defined as 'heavily modified water body' (HMWB). The main objective of the WFD is to achieve a good ecological status of natural water bodies and a good ecological potential for HMWBs. Many efforts have been made in the last 18 years to evaluate natural water bodies. On the contrary, HMWBs have been left aside. The designation of a water body as heavily modified is basically due to economic reasons, as it would be extremely expensive to recover those areas to their natural condition [1]. Hence, the designation of reference conditions for HMWB becomes complicated. Nonetheless, in this study we hypothesize that the pollution in HMWBs may greatly influence adjacent natural coastal waters, which makes it necessary to make further effort in their evaluation.

In order to set environmental objectives within the WFD, Member States must evaluate several biological, hydromorphological and physicochemical quality elements which together determine the status of water bodies. Nutrient over enrichment due to anthropogenic activity is considered as one of the most important water quality problems. As such, nutrient conditions are used as a physicochemical indicator of the ecological status. Coastal ecosystems receive nutrients either directly from the sources on the coastline or from rivers that bring nutrients from their catchments, via sea current transport from distant coastal and marine waters, and from the atmosphere [2]. In this study we analyse nutrient concentrations as a physicochemical indicator of ecological status of coastal waters.

\subsection{Anthropogenic pressure assessment}

The assessment of anthropogenic pressures to coastal waters is essential to set management plans. As such, several anthropogenic indexes have been developed. LUSI index (Land Uses Simplified Index) was developed by [3] and is the recommended pressure index in the context of the Mediterranean Geographical Intercalibration Group. It has been widely applied in different areas of the Mediterranean Sea [4]-[7]. This index is based on the different land uses of areas limiting the studied coastal water, as well as on the morphology of the coastline (concave or convex). Despite the usefulness proved by this index, some limitations exist. For instance, [8] adapted the mentioned index to the Valencian coast in Spain and developed the named LUSIVal index. This new index included additional pressures such as rivers and harbours. [9] added two descriptors to the calculation of LUSI index: population pressure and the artificialization rate of the rocky shore and developed the MA-LUSI-WB index. [10] proposed the Cumulative Human Impact Index (CHII) which takes into account 10 different pressures: man-made coastline, boat anchoring, aquaculture, urban effluents, industrial effluents, urbanisation, agriculture, coastline erosion, coastal population and fishing. Nonetheless, the inclusion of more and more parameters to anthropogenic pressure indexes may not add value to the assessment and definitely makes it more complicated for management purposes. [4] proposed an index (HAPI) to identify those pressures likely to have a real impact. In this paper, we analyse the main sources of nutrient disturbances in natural water bodies to allow water managers to efficiently propose recovery measures.

\section{STUDY SITE}

\subsection{Description}

All coastal waters in the Jucar River Basin District (JRBD) belong to the Mediterranean ecoregion. Most of Jucar's coastal waters are shallow $(<30 \mathrm{~m})$, to a less extent intermediate 
(30-50m), and sometimes deeper than 50m but never reach $100 \mathrm{~m}$ [11]. As defined in the Jucar river basin management plan, 22 water bodies have been identified as coastal water bodies, among which 6 have been defined as heavily modified due to the presence of a harbour. Fig. 1 shows a map of the JRBD with the location of each coastal water body [11].

In the JRBD we find two typologies for coastal waters:

- Type II-A (C001 to C010): moderately influenced by freshwater inputs (continent influence), salinity between 34.5 and $37.5 \mathrm{~kg} . \mathrm{m}-3$

- Type III-W (C011 to C017): not influenced by freshwater input (Western Basin), salinity $>37.5 \mathrm{~kg} / \mathrm{m} 3$

[8] determined the main nutrient pressures to the Jucar River Basin District: urbanization, industry, agriculture, rivers and harbours. Similarly, they also considered that adjacent water bodies may significantly affect nutrient concentrations. As such, in this study we considered the following pressures: agricultural area, nitrogen and phosphorus direct inputs (from both urban and industry), area of limiting HMWB and the number of rivers discharging into the water body. This data is presented in Table 1.

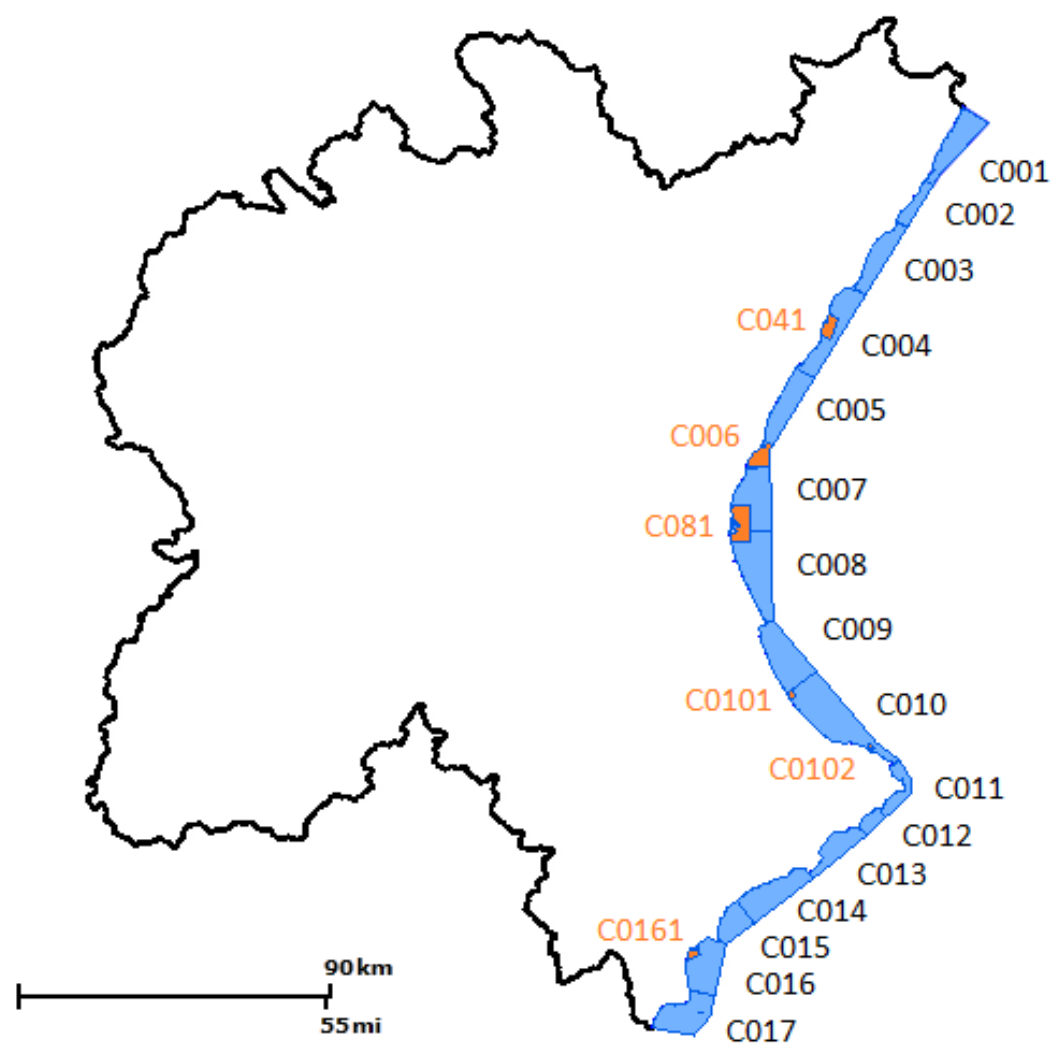

Figure 1: Jucar River Basin District. Natural coastal water bodies (blue) and heavily modified coastal water bodies (red). (Source: Adapted from http://aps.chj.es/ idejucar/.) 


\subsection{Anthropogenic pressures}

Table 1: Main nutrient pressures to Jucar River Basin Ditrict's coastal waters. (Source: Local government.)

\begin{tabular}{|c|c|c|c|c|c|c|}
\hline \multirow[b]{2}{*}{ Water body } & \multirow[b]{2}{*}{$\begin{array}{l}\text { Area } \\
\left(\mathrm{km}^{2}\right)\end{array}$} & \multicolumn{5}{|c|}{ Pressures } \\
\hline & & $\begin{array}{l}\text { Agricultural } \\
\text { area }\left(\mathrm{km}^{2}\right)\end{array}$ & $\begin{array}{l}\mathrm{N} \text { inputs } \\
\left(\text { tonN. } \mathrm{yr}^{-1}\right)\end{array}$ & $\begin{array}{l}\text { P inputs } \\
\text { (tonP.yr-1) }\end{array}$ & $\begin{array}{c}\text { Area of } \\
\text { limiting } \\
\text { HMWB (m) }\end{array}$ & Rivers \\
\hline $\mathrm{C} 001$ & 130 & 10132 & 309 & 49 & 0 & 2 \\
\hline $\mathrm{C} 002$ & 44 & 33 & 11 & 1 & 0 & 0 \\
\hline $\mathrm{C} 003$ & 106 & 4418 & 25 & 4 & 0 & 1 \\
\hline $\mathrm{C} 004$ & 141 & 24844 & 115 & 10 & 21 & 2 \\
\hline $\mathrm{C} 005$ & 122 & 24311 & 14 & 4 & 35 & 2 \\
\hline $\mathrm{C} 007$ & 152 & 16734 & 181 & 7 & 89 & 0 \\
\hline $\mathrm{C} 008$ & 197 & 67650 & 0 & 0 & 54 & 0 \\
\hline $\mathrm{C} 009$ & 171 & 63748 & 2 & 0 & 0 & $3 *$ \\
\hline $\mathrm{C} 010$ & 268 & 22752 & 71 & 16 & 7 & 3 \\
\hline $\mathrm{C} 011$ & 57 & 1532 & 16 & 5 & 0 & 1 \\
\hline $\mathrm{C} 012$ & 31 & 0 & 19 & 2 & 0 & 0 \\
\hline $\mathrm{C} 013$ & 89 & 2724 & 191 & 35 & 0 & 1 \\
\hline $\mathrm{C} 014$ & 147 & 1348 & 0 & 0 & 0 & 2 \\
\hline $\mathrm{C} 015$ & 76 & 2281 & 0 & 0 & 0 & 0 \\
\hline $\mathrm{C} 016$ & 134 & 1593 & 133 & 21 & 9 & 0 \\
\hline $\mathrm{C} 017$ & 144 & 9555 & 1 & 0 & 0 & 0 \\
\hline
\end{tabular}

* Jucar river was included as 2, as it is considerably larger than other rivers of the Basin.

\section{STATISTICAL ANALYSIS}

\subsection{Nutrient boxplot}

The Commission Decision 2013/480/EU established a period of five years to determine the ecological status of coastal waters under the WFD. Therefore, for this study measures taken monthly for a period of 5 years was used: January 2006 to December 2010. Ammonium, nitrate and total phosphorus were measured monthly in several stations of each natural water body as described in [12]. Results are presented in a box plot in Fig. 2.

\subsection{Pearson correlations analysis}

To determine which factors mostly affect nutrient concentrations (ammonium, nitrate and total phosphorus) in coastal waters, Pearson correlations between nutrients and pressures presented in section 2.2 was evaluated. As water bodies have different total surfaces, 

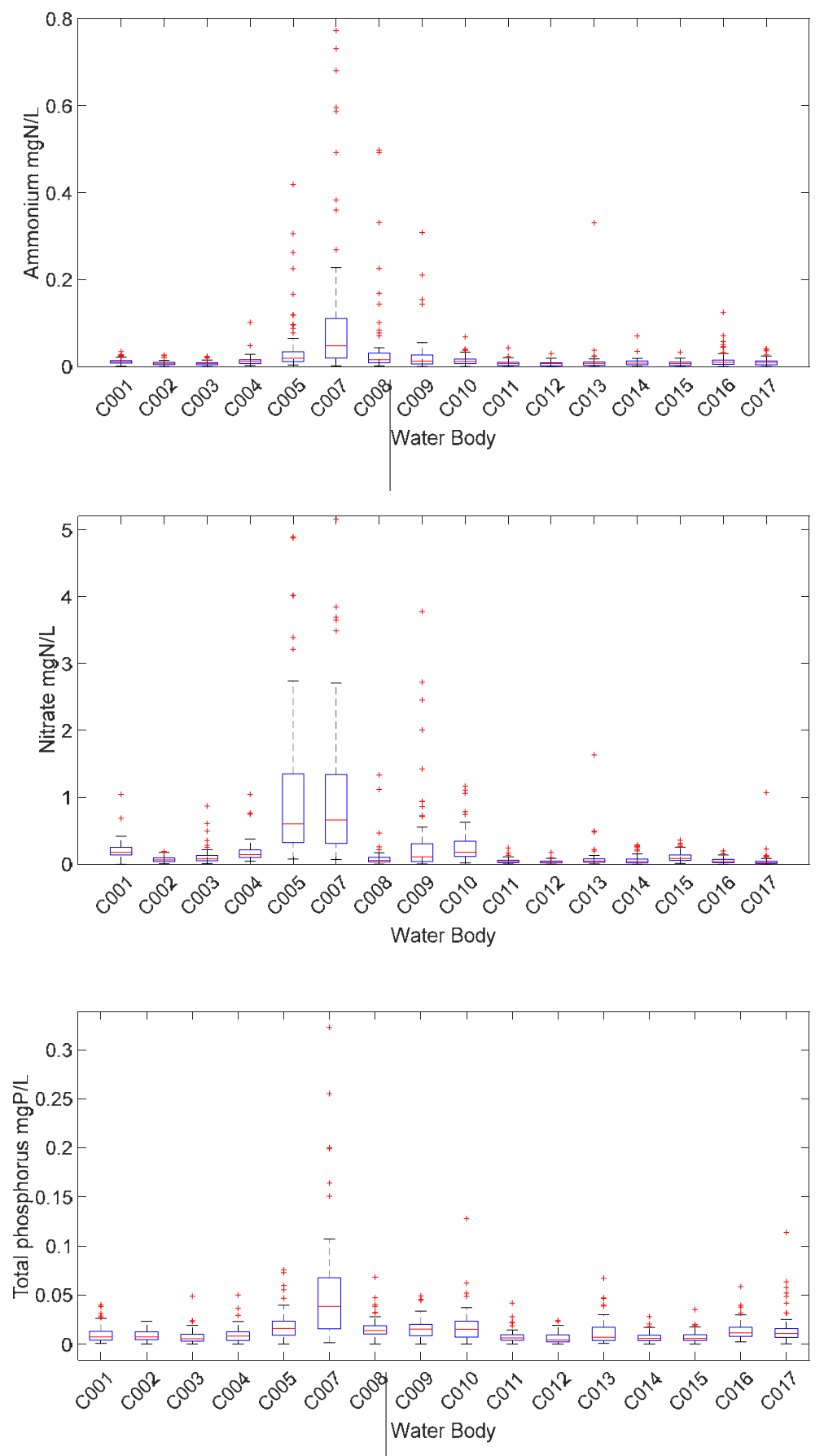

Figure 2: Nutrient concentration boxplot. Monthly measures from January 2006 to December 2010. 
Table 2: Pearson correlations between nutrient concentrations (ammonium, nitrate and total phosphorus) and main pressures. Significant correlations $(\alpha<0.05)$ are marked with an asterisk. X1: agricultural area/water body area $\left(\mathrm{km}^{2} / \mathrm{km}^{2}\right) ; \mathrm{X} 2$ : $\mathrm{N}$ inputs/water body area (tonP. $\left.\mathrm{yr}^{-1} / \mathrm{km}^{2}\right) ; \mathrm{X} 3$ : $\mathrm{P}$ inputs/water body area (tonN.yr-1/ $\left.\mathrm{km}^{2}\right)$; X4: area of limiting HMWB/water body area $\left(\mathrm{km}^{2} / \mathrm{km}^{2}\right) ; \mathrm{X} 5$ : number of rivers discharging into the water body.

\begin{tabular}{|c|c|c|c|}
\hline & Ammonium & Nitrate & Total phosphorus \\
\hline $\mathrm{X} 1$ & 0.49 & 0.36 & 0.38 \\
\hline $\mathrm{X} 2$ & 0.05 & 0.02 & 0.07 \\
\hline $\mathrm{X} 3$ & -0.17 & -0.12 & -0.14 \\
\hline $\mathrm{X} 4$ & $0.97^{*}$ & $0.74^{*}$ & $0.84^{*}$ \\
\hline $\mathrm{X} 5$ & -0.12 & 0.25 & -0.06 \\
\hline
\end{tabular}

pressures were divided by the area of each water body. Correlations were calculated with Statgraphics Centurion and results are presented in Table 2. Direct inputs of nitrogen (X2) or phosphorus (X3) do not have a significant correlation, and neither does the agricultural area (X1) or rivers (X5). On the other hand, all three studied nutrients have a significant correlation $(\alpha<0.05)$ with the area of limiting HMWB (X4), suggesting that the proximity of HMWB may be the main driver of the differences observed in nutrient concentrations. These results suggest that nutrient loads to HMWB may be the main source of pollution to adjacent natural coastal waters through diffusion.

\subsection{Stepwise linear regression}

Three forward stepwise multiple lineal regressions were run in Statgraphics Centurion, one for each studied nutrient. The dependent variables (ammonium, nitrate and total phosphorus respectively) were log-transformed to normalize the variables and obtain normally distributed residuals. Results are presented in Table 3. All three models were found to be statistically significant as shown by $\mathrm{R}^{2}$, adjusted $\mathrm{R}^{2}$ and $\mathrm{p}$-value indicated in Table 4 . DurbinWatson statistic tests the residuals to determine if there is any significant correlation based on the order in which they occur in the data. As observed in Table 4, there is no indication of serial autocorrelation in the residuals at the $95 \%$ confidence level. Multicolineality was not detected between any of the coefficients of the three fitted models.

Nutrient concentrations were estimated with the results of the linear regression (eliminating log-transformation) and results are plotted in Fig. 3 together with measured values. As determined by $\mathrm{R}^{2}$ showed in Fig. 3, a good correlation was found between estimated and measured concentrations. Ammonium estimations have small deviations from measured values $\left(\mathrm{R}^{2}=0.9660\right)$. Nitrate has also a good model fit $\left(\mathrm{R}^{2}=0.8329\right)$; however, the model shows a deviation in $\mathrm{C} 005$ which may indicate a source of pollution not considered in this study. Total phosphorus is the least well estimated nutrient $\left(\mathrm{R}^{2}=0.7586\right)$ presenting little coincidence with measured data from $\mathrm{C} 009$ to $\mathrm{C} 017$. Other pressures not considered in the study may be affecting total phosphorus concentrations in addition to the proximity of HMWBs. 
Table 3: Results of forward stepwise linear regression with fitted variables. Model 1, Model 2 and Model 3 are respectively the models obtained with ammonium, nitrate and total phosphorus concentration as the independent variable. X1: agricultural area/water body area $\left(\mathrm{km}^{2} / \mathrm{km}^{2}\right) ; \mathrm{X} 4$ : area of limiting HMWB/water body area $\left(\mathrm{km}^{2} / \mathrm{km}^{2}\right)$; X5: number of rivers discharging into the water body.

\begin{tabular}{|c|c|c|c|c|}
\hline Parameter & Estimate & Standard error & T Statistic & P-Value \\
\hline \multicolumn{5}{|c|}{ Model 1 (ammonium) } \\
\hline CONSTANT & -4.7475 & 0.0732 & -64.84 & 0.0000 \\
\hline X1 & 0.0026 & 0.0005 & 4.94 & 0.0003 \\
\hline X4 & 3.4639 & 0.3669 & 9.44 & 0.0000 \\
\hline \multicolumn{5}{|c|}{ Model 2 (nitrate) } \\
\hline CONSTANT & -2.9872 & 0.1836 & -16.27 & 0.0000 \\
\hline X4 & 4.5505 & 0.7408 & 6.14 & 0.0000 \\
\hline X5 & 0.5284 & 0.1086 & 4.87 & 0.0003 \\
\hline \multicolumn{7}{|c|}{ Model 3 (total phosphorus) } \\
\hline CONSTANT & -6.8287 & 0.1188 & -57.47 & 0.0000 \\
\hline X4 & 3.9452 & 0.6544 & 6.03 & 0.0000 \\
\hline
\end{tabular}

Table 4: Model results' interpretation: R2, standard error, Durbin-Watson test and ANOVA test results. Model 1, Model 2 and Model 3 are respectively the models obtained with ammonium, nitrate and total phosphorus concentration as the independent variable.

\begin{tabular}{|c|c|c|c|}
\hline Model & 1 (ammonium) & 2 (nitrate) & $\begin{array}{c}3 \text { (total } \\
\text { phosphorus) }\end{array}$ \\
\hline $\mathrm{R}^{2}$ & 0.9298 & 0.7998 & 0.7220 \\
\hline $\mathrm{R}^{2}$ adjuted & 0.9190 & 0.7690 & 0.7021 \\
\hline Standard error & 0.2173 & 0.4641 & 0.4118 \\
\hline Drubin-Watson statistic & 2.2179 & 2.4111 & 2.7132 \\
\hline Drubin-Watson p-value & 0.5580 & 0.7064 & 0.9047 \\
\hline ANOVA F-Ratio & 86.04 & 25.97 & 36.35 \\
\hline ANOVA p-value & 0.0000 & 0.0000 & 0.0000 \\
\hline
\end{tabular}



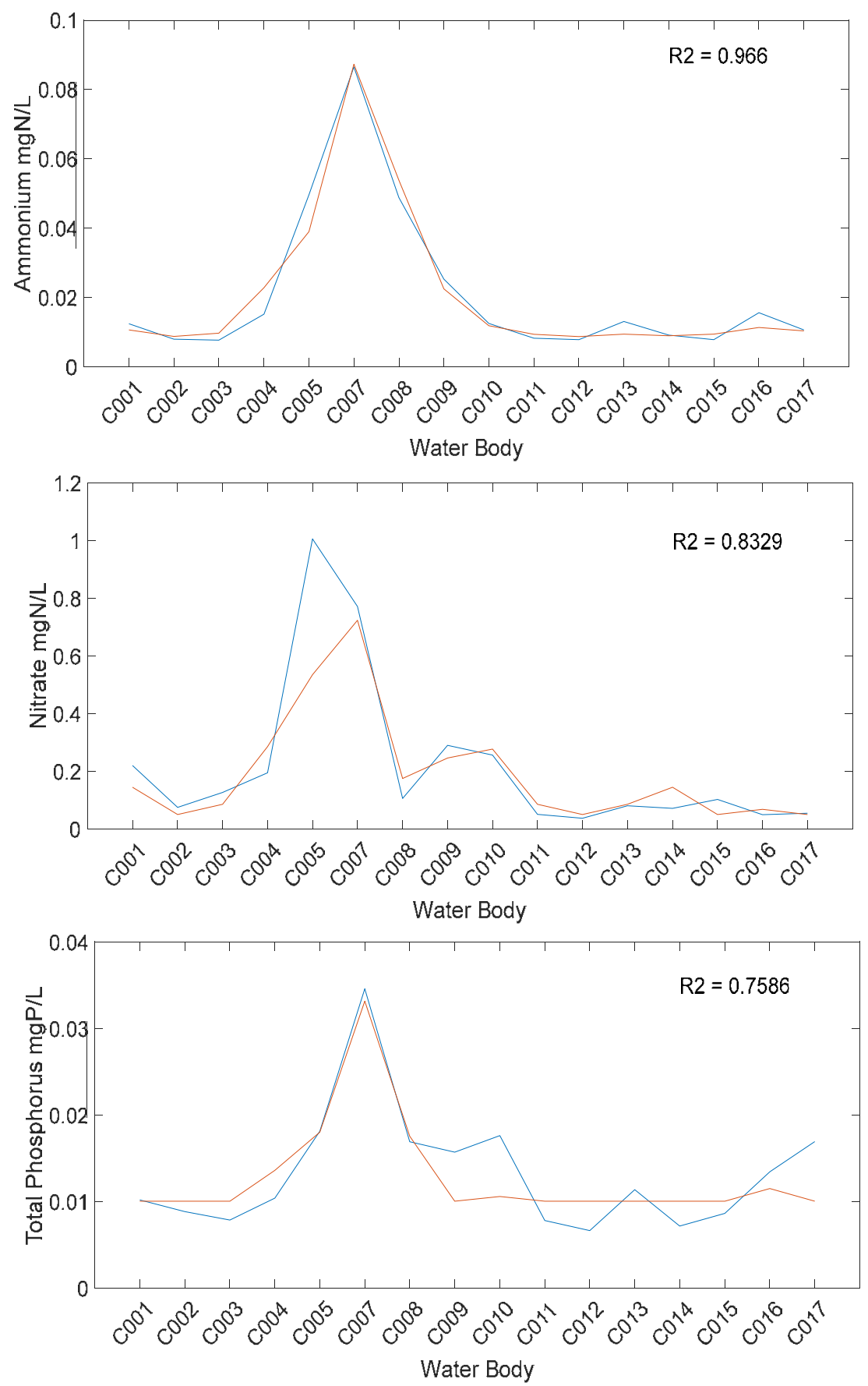

Figure 3: Measured nutrient concentrations (blue) and estimated (red) by means of forward stepwise linear regression. 


\section{CONCLUSION AND FUTURE WORK}

Pearson correlation coefficients suggest that only the proximity of HMWBs has a significant relationship with all three nutrient concentrations. Similarly, the stepwise linear regression performed determined that the vicinity of a HMWB is a decisive factor for nutrient concentrations in natural coastal water bodies. Ammonium may also be influenced by the agricultural area and nitrate by the discharge of rivers. Nonetheless, for the three nutrients studied, the proximity of a HMWB was the main factor driving the difference of concentrations among natural coastal waters.

Previous studies also determined that harbours influence nutrient concentrations [8], [10], [13]. However, harbours are usually considered as a secondary source of nutrients. Our results show that HMWB, which are set around big ports, might be the main source of pollution. Often HMWBs are located in the biggest urban areas, which are the principal source of nutrients to coastal waters. When HMWB are excluded from the assessment of anthropogenic pressures, an important source of pollution is overlooked. The results obtained in this study suggest that if natural coastal waters are to be recovered, attention needs to be given to HMWBs.

The assessment of coastal waters and the proposition of recovery measures should be made by considering coastal water bodies as interrelated and not solely evaluated independently. Moreover, greater attention should be given to HMWBs, as the main source of pollution to coastal waters may come from these water bodies. In future work, the dispersion of pollutants from HMWBs to natural water bodies should be further evaluated to determine whether HMWBs are indeed the main source of pollution. Methods aiming at assessing anthropogenic pressures, such as indexes, should include the assessment of heavily modified coastal waters.

\section{ACKNOWLEDGEMENT}

Field data collection was supported by the Regional Ministry of the Environment, Water, Urban Planning and Housing.

\section{REFERENCES}

[1] Borja, A. \& Elliott, M., What does "good ecological potential" mean, within the European Water Framework Directive? Marine Pollution Bulletin, 54(10), pp. 15591564, 2007.

[2] European Commission. Common Implementation Strategy for the Water Framework Directive (2000/60/EC). Guidance document No. 23: Guidance document in eutrophication assessment in the context of European water policies, http://ec.europa.eu/environment/water/water-framework/. Accessed on: 25 Apr. 2018.

[3] Flo, E., Camp, J. \& Gracés, E., Land uses simplified index (LUSI): A simple method to assess continental pressures on coastal waters. Proceedings of ECSA Conference: Estuaries and Coastal Seas in a Rapidly Changing World, London, United Kingdom, 2015.

[4] Blanfuné, A. et al., The CARLIT method for the assessment of the ecological quality of European Mediterranean waters: Relevance, robustness and possible improvements. Ecological Indicators, 72, pp. 249-259, 2017.

[5] Tan, I., Beken, C.P. \& Oncel, S., Pressure-Impact analysis of the coastal waters of Marmara Sea. Fresenius Environmental Bulletin, 26(4), pp. 2689-2699, 2018.

[6] Nikolić, V., Žuljević, A., Mangialajo, L., Antolić, B., Kušpilić, G. \& Ballesteros, E., Cartography of littoral rocky-shore communities (CARLIT) as a tool for ecological 
quality assessment of coastal waters in the Eastern Adriatic Sea. Ecological Indicators, 34, pp. 87-93, 2013.

[7] Ninčević-Gladan, Ž. et al., The response of phytoplankton community to anthropogenic pressure gradient in the coastal waters of the eastern Adriatic Sea. Ecological Indicators, 56, pp. 106-115, 2015.

[8] Romero, I., Pachés, M., Martínez-Guijarro, R. \& Ferrer, J., Glophymed: An index to establish the ecological status for the Water Framework Directive based on phytoplankton in coastal waters. Marine Pollution Bulletin, 75, pp. 218-223, 2013.

[9] Torras, X., Pinedo, S., García, M., Weitzmann, B. \& Ballesteros, E., Environmental quality of Catalan coastal waters based on macroalgae: the interannual variability of CARLIT index and its ability to detect changes in anthropogenic pressures over time. The Handbook of Environmental Chemistry, 43, 2015.

[10] Holon, F. et al., Fine-Scale cartography of human impacts along French Mediterranean coasts: a relevant map for the management of marine ecosystems. PLOS ONE, 10(8), e0135473, 2015.

[11] Confederación Hidrográfica del Júcar, Plan hidrológico de la Demarcación hidrográfica del Júcar. Memoria, Ciclo de planificación hidrológica 2015-2021. www.chj.es/es-es/medioambiente/planificacionhidrologica/Paginas/PHC-2015-2021Plan-Hidrologico-cuenca.aspx, Accessed on: 25 Apr. 2018.

[12] Pachés, M., Romero, I., Hermosilla, Z. \& Martinez-Guijarro, R., PHYMED: An ecological classification system for the Water Framework Directive based on phytoplankton community composition. Ecological Indicators, 19, pp. 15-23, 2012.

[13] Lopez y Royo, C., Silvestri, C., Pergent, G. \& Casazza, G., Assessing human-induced pressures on coastal areas with publicly available data. Journal of Environmental Management, 90(3), pp. 1494-1501, 2009. 